\title{
Management of Tropical River Basins and Reservoirs under Water Stress: Experiences from Northeast Brazil
}

\author{
Érika Tavares Marques ${ }^{1, *}$, Günter Gunkel ${ }^{2}$ (D) and Maria Carmo Sobral ${ }^{1}$ \\ 1 Center of Technology and Geosciences, Federal University of Pernambuco (UFPE), Recife 50740-550, Brazil; \\ msobral@ufpe.br \\ 2 Chair Water Quality Control, Berlin University of Technology, Berlin 10623, Germany; \\ guenter.gunkel@water-quality-control.de \\ * Correspondence: erikambio@gmail.com
}

Received: 18 April 2019; Accepted: 28 May 2019; Published: 4 June 2019

\begin{abstract}
Due to global warming, a reduction in available water will occur in many watersheds and conflicts concerning water use will take place. This situation is already typical in semi-arid areas, where many reservoirs have been constructed for water storage. Increased energy demands and climate change have led to severe and increasing pressure on aquatic systems. Today, the environmental policies of many countries, such as Brazil, give priority to constructing new reservoirs for hydropower use, and an adopted reservoir and river basin management plan must minimize environmental impacts. Moreover, the production of energy plants will promote more requirements for new dam projects. The Itaparica reservoir is 30 years old, located in the São Francisco river in Northeast Brazil, and is the focus of an environmental study. The article focus of investigations is on the environmental and social impacts after the construction of Itaparica reservoir, governance difficulties, and adopted actions to minimize those impacts. Significant environmental impacts are recognizable, such as increased sedimentation in the inflow area, damage to the lakeshore zone by operational water level variation, water losses by evaporation and infiltration, and degradation of inundated vegetation. Furthermore, a trophic upsurge has been registered with severe eutrophication processes, such as the occurrence of cyanobacteria, oxygen deficit in the hypolimnion, and mass development of macrophytes (Egeria densa). With the creation of the dam there was compulsory displacement of the population of the municipalities around Itaparica reservoir with consequent difficulties of adaptation in the new spaces. Furthermore, there was de-structuring of social relation networks, loss of arable land and improvements, and small and insufficient indemnities for land. In this context, concepts for an advanced reservoir management under consideration of water scarcity are presented and discussed. This study aims to contribute to sustainable reservoir management
\end{abstract}

Keywords: reservoirs; eutrophication; Itaparica; São Francisco river; water management; river basin

\section{Introduction}

Worldwide construction and operation of tropical reservoirs for energy production, irrigated agriculture, and flood control is of high importance and requires good water management to guarantee sustainable water use. However, experiences from the last decades point out increasing problems due to sewage input, increasing population with inadequate wastewater treatment, as well as impacts and uncertainties due to climate change effects. River basins under water stress due to climate change is a new experience for many countries, and a focus must be put on developing a new and adapted watershed management, considering the growing population with an increase in economic development and food demands, as well as more frequent droughts and the need for more ambitious protection of biodiversity and ecological flow. 
Many already constructed reservoirs or those which are still in the planning process are mainly destined for hydroelectric power and flood regulation, both being of high significance to guarantee better quality of life. However, nowadays due to the increasing importance of environmental policies, a more differentiated use of water must be implemented as a consequence of socio-economic development, protection of drinking water supply, and conservation of aquatic ecosystems, all having a high and increasing priority in environmental policy.

Reservoir operations have already been provoking conflicts in relation to the multiple uses of water. These conflicts will increase with extreme climate periods, such as extended droughts or flash floods. Multiple uses of reservoirs include generating hydroelectric energy, flood regulation, urban and industrial water supply, agriculture irrigation, withdrawal of water for aquaculture, net cage culture in the reservoir, fishing, navigation, recreation, and tourism. Any multiple water use implies an integrated river basin management and regionally adopted water management, which includes land use and social-economic development, water and land usage, as well as aquatic ecosystem dynamics [1-3].

The model of water management in Brazil, currently in force, is the result of a process which broadly began in the 1970s to the 1980s [4,5]. Law No. 9433, also known as the "Water Law", came into force in 1997, establishing the National Policy of Water Resources (known as PNRH) and creating the National Water Resources Management System (known as SINGREH) and the National Water Agency (ANA). Inspired by the French model, the Brazilian water management presupposes decentralized, participatory, and integrated management. The Water Law is based upon six foundations and established five management instruments, as shown in Table 1. Based on such foundations and management instruments, ANA aims to make sure that different water usages are complementary, with one use not hindering another, while also considering the need to prevent critical water-related events [6].

Table 1. Foundations and management instruments of Water Law No. 9433.

\begin{tabular}{|c|c|}
\hline Foundations & Instruments \\
\hline Water is a collective asset; & \multirow{2}{*}{ Plans for Water Resources } \\
\hline Water is a limited natural resource endowed with economic value & \\
\hline $\begin{array}{l}\text { In situations of water resources scarcity, priority of use will be } \\
\text { given to human consumption and quenching animal thirst }\end{array}$ & $\begin{array}{l}\text { The framework of water bodies in classes, } \\
\text { according to the compelling uses }\end{array}$ \\
\hline $\begin{array}{l}\text { Management of water resources should always provide for their } \\
\text { multiple uses }\end{array}$ & $\begin{array}{c}\text { The granting of rights to the use of water } \\
\text { resources }\end{array}$ \\
\hline $\begin{array}{c}\text { A river basin is the territorial unit of implementation of the } \\
\text { National Policy of Water Resources and of action of the National } \\
\text { Water Resources Management System }\end{array}$ & The charge for use of the water \\
\hline $\begin{array}{l}\text { Water resources management should be decentralized and count } \\
\text { with the participation of the government, users, and } \\
\text { communities }\end{array}$ & $\begin{array}{l}\text { The System of Information on Water } \\
\text { Resources }\end{array}$ \\
\hline
\end{tabular}

SINGREH is integrated by the National Council of Water Resources (CNRH), the National Water Agency (ANA), the state councils of water resources, the watershed committees, federal, state, and municipal institutions responsible for water resources management, and water agencies (Figure 1).

The Brazilian Constitution establishes the distribution of water dominance between the Union and the states, provided that management in the river basin is articulated between these actors. For this reason, the Brazilian system of governance and management involves, in addition to the federal sphere, the federal states, where different management institutions should harmonize their procedures so that the management of water resources can be carried out in an integrated way [7].

The laws mandated integrated management for multiple uses of water, to take place at the river basin level, and shared among multiple public and private interests via participatory basin committees and executive agencies. In principle, these were to be financed by the implementation of a bulk water 
charges system for users (e.g., industry, agriculture, sanitation companies, etc.). Hence, more than 100 river basin committees have been created in Brazil, following trends in other policy sectors to create stakeholder councils for public decision-making, with the participation of government, civil society, and the private sector [6].

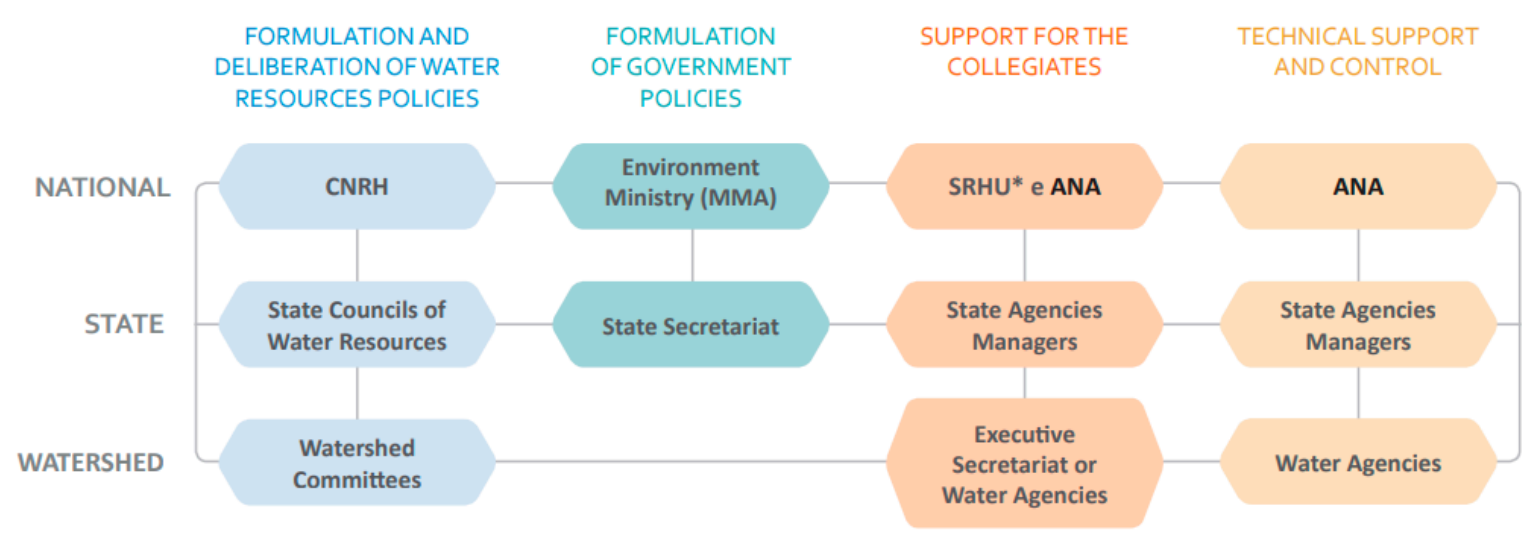

*Water Resources Secretariat and Urban Environment of the Environment Ministry.

Figure 1. Organization of the National System of Water Resources Management and the state systems [6].

A river basin is defined as a territorial unit for implementing the water resources policy and a basin committee as a managing body for this territorial unit, with important responsibilities, including conflict resolution, approval and monitoring of water resources plans, and setting up of systems for charging for water use.

Goals for integrated river basin management are to reduce water quality impact to guarantee long-term water uses [8,9]. Furthermore, it provides a reduction to impact on biodiversity, avoiding contamination by xenobiotics, water quantity management considering long-lasting droughts, and from a global point of view, the emission of greenhouse gases [10,11].

Water storage in reservoirs is extremely important in Northeast Brazil, because ground water resources are few, salty, and over exploited. Alternatives such as water harvesting and subsurface dams are not sufficient for water supply to larger urban areas [3]. Moreover, the alternative use of reservoirs for water storage in the tropical and semi-arid zone implies many problems concerning water quality and environmental impact $[12,13]$.

The occurrence of periodic droughts of great intensity in the Northeast with relevant impacts on its population and the quality of life has been registered [14]. Observation of reduced annual rainfall (less than $800 \mathrm{~mm}$ ), the vegetation, the crystalline subsoil and generally shallow soils are characteristics of the semi-arid region. This region is also characterized by hot temperatures, low thermal amplitudes (between $2-3{ }^{\circ} \mathrm{C}$ ), high sunshine, and evapotranspiration rates; evapotranspiration generally exceeds the irregular rainfall, setting negative rates in the water balance [15].

An evaluation of the environmental impacts of the 30-year-old Itaparica Reservoir (actually called Luiz Gonzaga Reservoir) in the São Francisco river has been the focus of a research program [12,16-18]. The São Francisco River has a length of $3160 \mathrm{~km}$ and is the 25th largest river worldwide, stretching from Minas Gerais in the rainy Southwest of Brazil, to the dry zone of Northeast Brazil. There are 8 reservoirs in the Middle and Lower-Middle course of the São Francisco river. Apart from generating electrical energy, the reservoirs are used for flood control and water supply. According to the Brazilian National Water Agency [19], the main use of water in the Lower-Middle course of the São Francisco River is irrigated agriculture, which represents $50.5 \%$ of the usage. The tributaries and the main course, as well as the reservoir, are continuously sucked up by pumps for irrigating crops and pastures, with and without authorization. The effects not only endanger the population throughout the basin, but also practically make navigation and other economic activities unfeasible in various parts of the river [20], and the minimum (ecological) flow is not provided throughout the year. 
The multiple uses of water are in reality reduced to only a few for energy production and for irrigation. The other uses are of less economic value and many of them have disappeared due to the impacts generated by the former. Thus, while fishing, navigation, and small flood cultures are losing strength, agribusiness of irrigated fruit and grain have grown with their new demands for energy and water. The options for farmers and fishermen are limited-seasonal migration to major centers in search of employment, or cultivation of exotic species in tanks of shrimp, tilapia (Oreochromis niloticus), tambaqui (Colossoma macropomum), or even the native surubim (Pseudoplatystoma corruscans) species [21].

After 30 years of operation, it is possible to make a comparative evaluation between the environmental impacts foreseen in the environmental study and the current environmental situation $[12,22,23]$. Until now, economic activities, such as irrigation agriculture and aquaculture, have been developed for the 40,000 relocated local population close to the reservoir's banks, which intensify the risk of degrading aquatic ecosystems and water quality due to uncontrolled use of agro-chemicals, fish feed, and a lack of sewage treatment. The article focuses its investigation on the environmental and social impacts after the construction of the Itaparica reservoir, governance difficulties, and adopted actions to minimize the impacts. This study aims to contribute to sustainable reservoir management.

\section{Material and Methods}

\subsection{The São Francisco River Basin (SFRB)}

The São Francisco river basin (SFRB) covers an area of approximately $640,000 \mathrm{~km}^{2}$, distributed in the states of Bahia, Minas Gerais, Pernambuco, Alagoas, and Sergipe. Eight reservoirs have been constructed up to the time of this study (2019): Sobradinho, Itaparica, Moxotó, Apolônio Sales, and Paulo Afonso I-IV, of which Sobradinho and Itaparica are the largest, situated in the middle course of the São Francisco river, all of which are managed by CHESF (Hydro Electric Company of São Francisco river basin). This presents densely populated and rich areas, as well as critical poverty and low demographic density, thus demonstrating various paradoxes of socioeconomic conditions and great environmental vulnerability.

The São Francisco basin includes fragments of the Atlantic Forest, Cerrado, Caatinga, Coastal, and Island biomes. There is a predominance of soils with aptitude for irrigated agriculture (latosols and podzolic) in the Upper, Middle, and Lower São Francisco. The region has about 35.5 million of arable hectares, with greater concentration in the vicinity of the valleys and urban areas. The region's economy is based on agriculture cultivation of soybeans and corn, livestock, with an emphasis on cattle and goat breeding, fisheries and aquaculture, industry and agribusiness, as well as mineral activities and activities related to tourism and leisure.

The evaluation of the current condition of the water bodies in the São Francisco river basin points out that main sources of pollution are domestic sewage, agriculture and livestock, and mining. The release of industrial and domestic effluents and provision of inadequate solid waste compromise the quality of tributary rivers, such as Paraopeba, Velhas, Pará, Verde Grande, Paracatu, Jequitaí, and Urucuia. Sedimentation annually causes a loss of $1 \%$ of reservoir capacity [24]. One indicator of this accelerated process of silting is the precarious navigability state of the São Francisco River.

The São Francisco river basin (Figure 2) has $94 \%$ of the installed capacity for hydroelectric power generation in Northeast Brazil, which represents about $70 \%$ of the total electric power generation capacity in this region.

The SFRB presents the smallest rainfall indices of Brazil, with annual precipitations normally below $800 \mathrm{~mm}$, average annual temperatures of 23 to $27^{\circ} \mathrm{C}$, and an evaporation average of 2000 $\mathrm{mm} / \mathrm{year}$, in addition to the irregular distribution of rainfall over the year. The climate of SFRB presents different types of climates according to Köppen's classification:

- In Higher São Francisco the predominant climate is Aw type—-hot and humid with summer rains; 
- The Middle São Francisco presents a predominant climate type of Aw, also presenting another climatic variation BShw, semiarid;

- The Sub-Middle São Francisco is classified as semiarid (BShw), with seven to eight dry months and an autumn rainfall regime with an annual total of about $550 \mathrm{~mm}$, mainly concentrated between the months of November and March;

- The Lower São Francisco presents a predominant climate of As—hot and humid with winter rains [25].

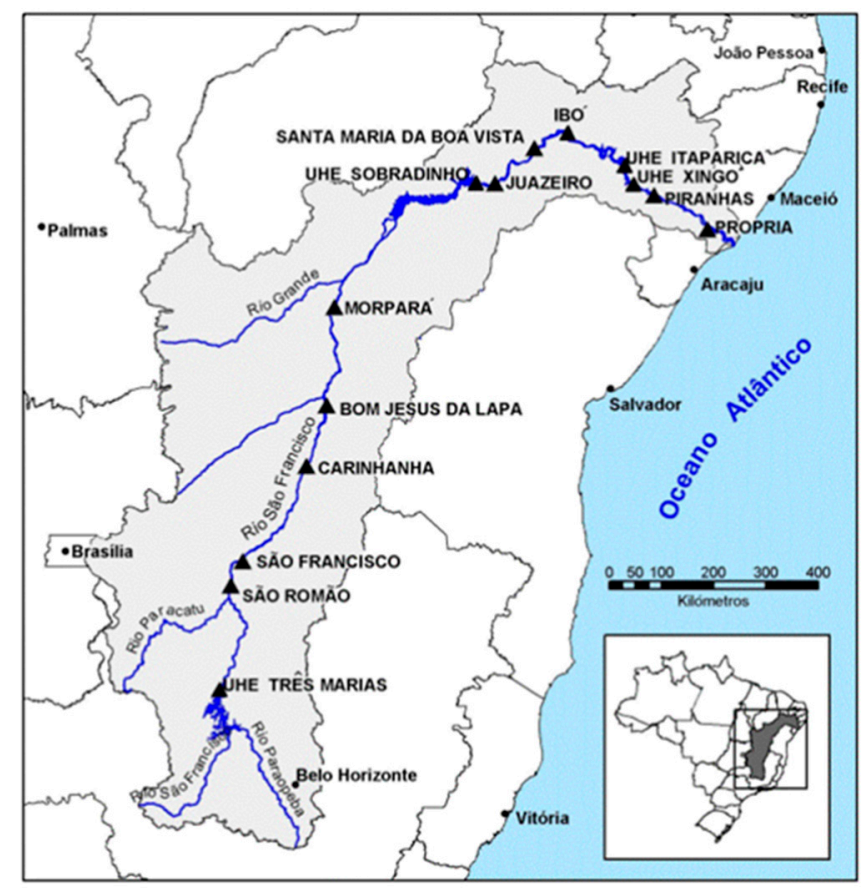

Figure 2. São Francisco River Basin (SFRB) and its insertion in the national territory, with main Hydropower Plants (HPPs) and fluviometric stations [26].

According to Sobral et al. [27], there are some distinctions in the index of climatic anomalies of the Sub-Middle São Francisco over time. Until the 1980's, positive values occurred in greater numbers, with the alternation of only two negative values. Then, a change in precipitation variation occurred in this decade, where dry years are more evident, showing possible climatic variation in the precipitation pattern in this region. This variation became more evident from the 1990's onwards, where it was observed that only dry years occurred between the years of 1990 and 2003, with no positive index or wet and rainy year. According to Marengo [28], these droughts provoked adverse effects on generating electric power (reduction), in the level of reservoirs (Table 2), and an increase in demand for thermoelectric energy, as well as an increase in the number of fires during the dry period. Moreover, the climate has a considerable influence on the dynamics of soil use and occupation, especially in the reservoir flow, with increase or decrease of the water volume. With these results, the aim is to show the importance of management and water in the catchment area, because if this trend of growing dry years is set as the standard, conflicts over water use will worsen.

Table 2. Average monthly natural floods in the Itaparica reservoir from 1931 to $2015\left(\mathrm{~m}^{3} \mathrm{~s}^{-1}\right)$ [29].

\begin{tabular}{c|cccccccccccc}
\hline Month & Jan & Feb & Mar & Apr & May & Jun & Jul & Aug & Sep & Oct & Nov & Dec \\
\hline Maximum & 9585 & 10,782 & 16,069 & 8336 & 9073 & 4417 & 2659 & 2119 & 1993 & 2011 & 4134 & 6221 \\
Minimum & 1307 & 1359 & 1294 & 1326 & 847 & 708 & 651 & 558 & 455 & 346 & 344 & 1098 \\
Average & 4672 & 4938 & 4934 & 4025 & 2426 & 1596 & 1312 & 1143 & 1022 & 1102 & 1763 & 3262 \\
\hline
\end{tabular}


The various interventions to which the river and its most important tributaries were subjected to in recent years have resulted in complex changes in its flow regime, with repercussions in its coastal zone [30]. Also, the São Francisco river basin has presented lower precipitation values than the historical average year after year since 2012, which have resulted in a significant reduction in the inflows to the hydroelectric reservoirs located in the river basin, leading them to the lowest storage levels ever recorded and placing them at risk for continued service to multiple uses of water (Figure 3). The Equivalent Reservoir of the São Francisco River-formed by the accumulations in Três Marias (MG), Sobradinho (BA), and Itaparica (between Bahia and Pernambuco) reservoirs-has been recording decreasing storage levels, reaching less than $5 \%$ of its useful volume at the end of the dry period in 2015 [15].

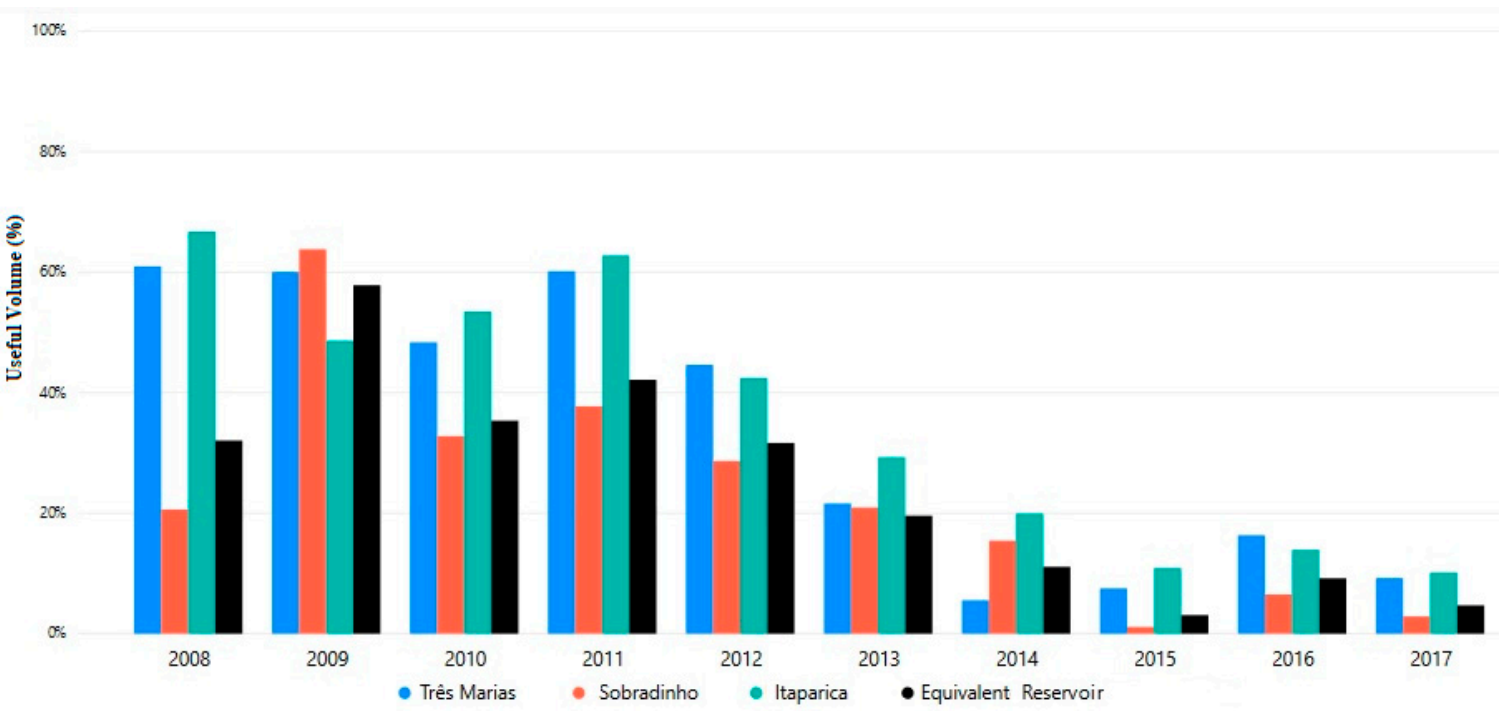

Figure 3. Useful volume of the reservoirs from the water system of the São Francisco river since 2008, showing hydroelectric plants of Três Marias, Sobradinho, Itaparica, and equivalent energy reservoir [31].

The equivalent energy reservoir (EER) is an abstraction of the total water volume in the reservoirs of the hydroelectric dams of a given subset. As the operating strategy must be calculated for all combinations of storage levels and hydrological trends, the problem of optimal system operation becomes rapidly intractable from the computational point of view. In the case of the Brazilian system, with more than 100 reservoirs, it is necessary to reduce the number of state variables by aggregating the several reservoirs of the same region into an equivalent reservoir of energy, thus defining an equivalent subsystem. For each subsystem, the reservoirs are aggregated into a single equivalent energy reservoir. The storage capacity of each equivalent reservoir is estimated by the energy produced by the complete emptying of the reservoirs of the subsystem, adopting the hypothesis of parallel operation. It also aggregates the affluent flows to each subsystem in equivalent energy inflows [32].

\subsection{Itaparica Reservoir}

The Itaparica reservoir was built by CHESF and construction began in 1979 and ended in 1988 when the reservoir was closed and the river diversion was concluded [33]. This reservoir was constructed below the Sobradinho Reservoir, with a regulated outflow of $2060 \mathrm{~m}^{3} \mathrm{~s}^{-1}$. It is located between Bahia and Pernambuco states, $290 \mathrm{~km}$ from the Atlantic Ocean. The Itaparica dam was constructed for hydroelectric power generation (1479 MW); for nearly 40,000 translocated people, a new economic basis with irrigation agriculture had to be developed. The reservoir has a length of $149 \mathrm{~km}, 828 \mathrm{~km}^{2}$ surface, maximum depth of $101 \mathrm{~m}$ and mean depth of $18 \mathrm{~m}$, and a capacity of $10.7 \times 10^{9} \mathrm{~m}^{3}$. The dam wall length is $4700 \mathrm{~m}$. Nowadays, the reservoir is also used as the water supply for irrigation agriculture, drinking water, fisheries, and aquaculture. 
The planning process for the dam, which was built with the major goal of energy production, took place in the 1970s, when an environmental audit was not part of the permission requirements. Therefore, environmental protection programs were quite limited. Later, in 1986, the Resolution CONAMA No. 01/1986 [34] established the obligation of environmental impact studies for specific projects, and the environmental study of the Itaparica Reservoir performed in 1987 had a pioneering role in Northeast Brazil [22].

According to Northeast Development Superintendence [35], the area has a hot and dry semi-arid climate with summer-autumn rains (BShw of Köppen climatic classification), whose annual precipitation decreases from southeast to northeast. It varies between $448 \mathrm{~mm}$ in the area of old Petrolândia city, which is now submerged, located about $10 \mathrm{~km}$ south of Apolônio Sales, and $403 \mathrm{~mm}$ for the town of Icó, near Icó-Mandantes. The rainy period extends from May to July, with the driest period occurring from September to November. Annual average temperatures are around $26^{\circ} \mathrm{C}$, and there is a very high annual evaporation rate of $2386 \mathrm{~mm}$ [36].

The geology of the area is mainly made up of sandy formations of the sedimentary basin of Jatobá, forming the plain and soft wavy relief of the study area. Its altitude varies from $300 \mathrm{~m}$ to slightly over $500 \mathrm{~m}$. It is mostly composed of quartz latosoil sands [37]. Sands in the area from Petrolândia to Ibimirim and Pernambuco State are very deep, excessively drained, strong to extremely acidic, and have low to very low natural fertility [38]. They are characteristic soils of the irrigation area of the village of Icó-Mandantes and only enable limited agricultural usage [39].

The biome of the area influenced by the Itaparica Reservoir is hyperxerophilic Caatinga, with the presence of Umbuzeiro (Tuberosa spondias), Juazeiro (Juazeiro zizyohus), Mandacaru (Cereus famacuruos), and Acácia (Acaria spp.) as typical salt tolerant species.

Monitoring of water quality and fishing activities was carried out before and after the reservoir fulfilment and during the first year of operation. Another significantly more complex monitoring program was conducted during 2004-2005, and during other subsequent periods by CHESF.

\subsection{Water Transposition Project}

The Federal Ministry of National Integration has additionally started operating a transposing water project, whose objective is to carry about $30-60 \mathrm{~m}^{3} \mathrm{~s}^{-1}$ water from the Itaparica reservoir to other Northeast States to assure the socio-economic development in this semi-arid area [19]. The purpose of this project is to transfer waters from the São Francisco river basin to the rivers in the Northeast through the East and North Axes. The project promises to guarantee water security for 12 million people in 390 municipalities in the states of Pernambuco, Ceará, Rio Grande do Norte, and Paraíba, covering seven hydrographic basins in the North axis and four basins in the East axis (Figure 4) [40,41].

Waters captured in the Itaparica reservoir are taken to other rivers, such as the Moxotó River, a tributary of the São Francisco, with large reservoirs, such as Poço da Cruz, in Ibimirim, and Pernambuco. Several reservoirs in this river basin are destined for multiple uses, within which is the Epitácio Pessoa dam, responsible for the urban water supply of 1 million inhabitants in Campina Grande and other cities [42].

\subsection{Water Quality Monitoring}

Monitoring reservoirs as an instrument for managing water resources consists of monitoring their water levels and the tributaries, serving as a support for the decision making on their operation in order to enable multiple uses of water resources. The National Water Agency (ANA) is responsible for defining and supervising the conditions for the operation of reservoirs by public and private agents in order to guarantee multiple uses of water resources, as established in the existing water resource plans, and in the case of reservoirs, these definitions are made in conjunction with the National Operator of the Electric System (ONS).

By filling the reservoirs, the water will be subject to low circulation, which can lead to eutrophication processes, excavation of the soils due to the water levels, which compromise the water quality and cause 
the mortality of aquatic organisms. If there is progressive flooding of the remaining vegetation when filling the reservoir, there will be an intense demand for oxygen for its stabilization (decomposition).

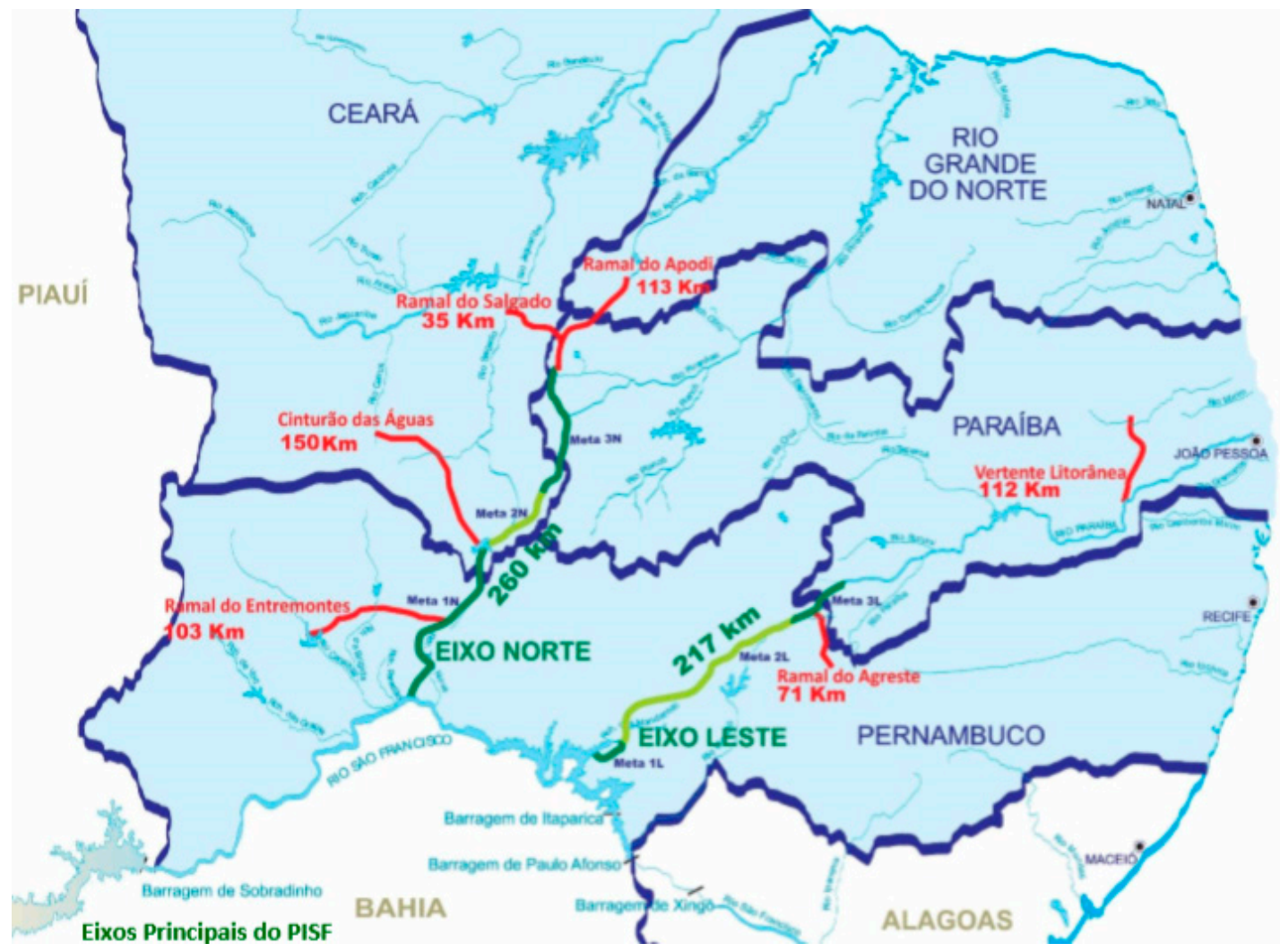

Figure 4. Location of the São Francisco River Basin Integration Project [43].

Some key elements for adequate reservoir monitoring are:

- Implement the Cleaning and Deforestation Program of the Reservoirs, with the removal of the biomass before filling in a selective manner, prioritizing deforestation, and cleaning vegetation in the range between the marginal limit and the depths of up to $10 \mathrm{~m}$, where the conditions of light penetration favor algae development;

- Conduct the water quality and limnology monitoring program;

- Monitor the natural sequence of species within the channels and reservoirs;

- Systematic inspection of reservoirs in relation to eutrophication.

CHESF is responsible for planning and conducting the water quality monitoring program. The following parameters are evaluated: nitrite, nitrate, ammonia, total phosphorus, inorganic phosphate, total dissolved solids, turbidity, dissolved oxygen, $\mathrm{pH}$, and conductivity levels.

\section{Results}

\subsection{Environmental Assessment of the Itaparica Reservoir}

According to Sobral et al. [22], the São Francisco River is considered as being nationally unifying, as it crosses seven Brazilian states. A series of 9 reservoirs have been constructed, with power generation as the main goal. Eight of these reservoirs are located in the semi-arid region of Brazil and are managed by CHESF. The operation of these reservoirs has been provoking conflicts in relation to multiple uses of water. These conflicts increase during extreme climatic periods, such as droughts and floods.

Reservoirs cause environmental impacts during their construction, as well as in their operation. They produce hydrological, atmospheric, biological, and social alterations in their influence area. Such 
impacts change the natural equilibrium of the river ecosystem and cause water quality deterioration, which intensify water use conflicts [44,45].

A series of environmental problems are observed related to the operation of Itaparica reservoir. The most relevant are:

- Absence of vegetation along the banks due to water level variations;

- Uncontrolled use of the banks of the reservoir for agricultural activities;

- Increasing use of shallow areas of the reservoir for aquaculture projects;

- Release of untreated domestic and industrial wastewater;

- Soil and bank erosion processes.

Concerning the Itaparica reservoir, in 1987, only one year before its fulfilment, an environmental impact study was presented for the purpose of receiving its operational environmental license [22]. The reservoir's construction was already in its final phase, and therefore this study did not influence the planning and construction process; furthermore, environmental impacts of urban and rural resettlement were analyzed in a very superficial way, mainly due to missing ecological studies about the affected area.

Furthermore, at the time of the reservoir construction in the prediction period of impacts, available knowledge was only based on the experience of temperate regions and emphasized the importance of plant biomass that would be submerged by flooding. One of the indications was that the decomposition of this biomass would add nutrients to the water and would deplete dissolved oxygen creating anoxic conditions, especially in the deeper areas of the reservoir [46].

In Brazil, the Environmental Impact Assessment (EIA) involves a set of methods and recognized environmental management techniques with the purpose of identifying, predicting, and interpreting effects and impacts on the environment resulting from proposed development actions. As a consequence of water containment, a dam causes the flooding of productive land, affecting the local fauna and flora which live in intimate dependence with the river, in addition to displacing residents of the riverine areas. The EIA is fundamental for understanding this interference in the environment, and to therefore propose measures to reduce or nullify the impacts.

From this point on, all works and activities which may have a deteriorating effect may be impaired. In addition to the principles and objectives of the National Environmental Policy Law, an environmental impact study should:

I. Contemplate all the technological alternatives and locations of the project, confronting them with an action of non-execution of the project;

II. Identify and systematically analyze the impacts generated in the implementation and operation phases of the activity;

III. Define the limits of the geographic area indirectly affected by the impacts and the denominated area of the project, considering, in all cases, the hydrographic basin in which it is located;

IV. To consider the governmental plans and programs, proposed and in execution in the area of influence of the project, and their compatibility (CONAMA Resolution $n^{\circ} .1$, article 5) [47].

According to Melo [48], a typology and characterization of a reservoir are important for planning deployment and management. Knowledge about the operating system of a reservoir becomes extremely interesting when considering their potential use for planning and managing a river basin, including water quality control.

\subsection{Water Quality Impacts on Dams}

The act of damming and impounding a river imposes a fundamental physical change upon the river continuum. The river velocity slows as it approaches the dam wall and the created reservoir becomes a lacustrine system. The physical change of damming leads to chemical changes within the reservoir, which alters the physical, chemical, and biological water quality, which in turn leads to ecological impacts on downstream rivers and associated wetlands [49]. 
The lower course of the São Francisco river and its reservoirs is determined to have climate variation, with a rainy season (May to July) and a dry season (September to November). Water temperatures are lower (about $26^{\circ} \mathrm{C}$ ) during the rainy season, and wind and precipitation lead to intensive water mixing, as well as increased concentrations of suspended sediments and nutrients due to wash off and erosion in the water basin. In contrast, inflow water temperatures increase up to $32{ }^{\circ} \mathrm{C}$ during the dry season and suspended sediments and available nutrient concentrations decrease because of low or missing export from the watershed.

Rapid eutrophication processes started after damming up the Itaparica reservoir, mainly due to mineralization of flooded vegetation and soils, a well-known process called trophic upsurge [50]. Several reservoir monitoring programs have been carried out by CHESF since 2004, as well as research programs concerning water quality, eutrophication processes, and water basin management [51-54].

The eutrophication process was calculated by the phosphorus load concept of Vollenweider [55], which led to a P load of $3.9 \mathrm{~g} \mathrm{~m}^{-2}$ year ${ }^{-1}$ after damming, being about 8 times higher than the critical load, which is calculated as phosphorus input per $\mathrm{m}^{2}$ and per year; this signifies the mesotrophic conditions of the reservoir [56]. This high P load led to an increase in algae, mainly cyanobacteria.

Trophic upsurge- and eutrophication-related processes were registered after completing the Itaparica Reservoir, such as the occurrence of cyanobacteria (Cylindrospermopsis raciborskii and Microcystis aeruginosa, among others), with a mass poisoning of people in 1988 [57].

The dried littoral zone is also used for cattle farming and agriculture, with a related input of nutrients and agrochemicals following an increase in water level. Due to the reduced flow rate and the water heating, nutrient rich river inflow from the Icó-Mandantes sub-water basin promotes an intensive development of phytoplankton among other occurring cyanobacteria, and Secchi transparency decreases to $<50 \mathrm{~cm}$. An alteration of phytoplankton to macrophyte dominance is promoted by the water level variation; phytoplankton increases due to nutrient input at low water levels and with the beginning of the rainy season, while at the end of the rainy season the submerged macrophytes grow and stretch up to $4 \mathrm{~m}$ with increasing water level and build up a very high biomass [58,59].

The water transparency in the Itaparica Reservoir of one to a few meters enables the development of submerged macrophytes, mainly the common waterweed (Egeria densa), which covers large areas of the reservoir with water depths $<7 \mathrm{~m}$. The reservoir water level then decreases during the dry season, and a complete breakdown of the submerged macrophytes occurs, and intense oxygen consumption in the hypolimnic water by degradation of the macrophytes is registered.

In the Itaparica reservoir, Egeria densa build up a high biomass with increasing water levels (about $5.2 \mathrm{~kg} \mathrm{~m}^{-2}$ wet weight). Then, the plants experience depths $<1 \mathrm{~m}$ with the decreasing water level, limiting their survival. The macrophyte stands break down and cause severe impact due to nutrient leaching (1.8 $\mathrm{g} \mathrm{m}^{-2}$ phosphorus and $22 \mathrm{~g} \mathrm{~m}^{-2}$ nitrogen), $\mathrm{O}_{2}$ consumption, and mechanical clogging of turbine inlets $[17,58]$. These leaching processes of sediment and dried macrophytes present the highest P source in the Icó-Mandantes bay.

Eutrophication also leads to the development of the water-borne disease schistosomiasis, because the population growth of the intermediate host snails of the Biomphalaria spp. genus increase due to the intensive development of the submerged macrophytes, which serve as a habitat for snails [60].

\subsection{Water Balance}

Using reservoirs for water storage, water losses by evaporation, transpiration, and infiltration (bank infiltration and losses to the aquifer) must be taken into account. The water losses by evaporation in the Itaparica reservoir amount to $66 \mathrm{~m}^{3} \mathrm{~s}^{-1}(=3 \%$ of the inflow), and additional water losses to the aquifer can occur because the raised water level after damming is much higher than the ancient aquifer level; fissures and fractures can also be responsible for water losses.

In 1991, the São Francisco river flow varied from $1570 \mathrm{~m}^{3} \mathrm{~s}^{-1}$ to $1776 \mathrm{~m}^{3} \mathrm{~s}^{-1}$ in the Itaparica area, and after damming the regulated outflow of the Sobradinho reservoir it was $2060 \mathrm{~m}^{3} \mathrm{~s}^{-1}$, but increased water abstraction occurred due to agricultural development and water transposition. Normal water 
level variation in the Sobradinho reservoir is $12 \mathrm{~m}$ (393.5-380.5 $\mathrm{m}$ above sea level) and in the Itaparica reservoir it is $5.5 \mathrm{~m}$ (304.5-299 $\mathrm{m}$ above sea level) [61].

During the severe drought experienced in the 2012-2018 period, continuous reductions of the minimum dewatering of the Sobradinho reservoir were carried out in order to guarantee attendance to multiple uses, from $1300 \mathrm{~m}^{3} \mathrm{~s}^{-1}$ in May 2103 to $550 \mathrm{~m}^{3} \mathrm{~s}^{-1}$ in October 2017. This drastic reduction in the volume contributed downstream of the Sobradinho reservoir lead to increased pressure among users and revealed the need for a minimum ecological flow that guarantees a good ecological state and sustainable water uses downstream.

\subsection{Thermal Regime of the Reservoir}

An important feature in the reservoirs related to the greater depth and the slow longitudinal velocity is the thermal and chemical stratification, especially in the region near the dam. Changes in water temperature and thermal stratification dynamics can cause negative effects on the physical, chemical, and biological processes of reservoirs. The temperature variation affects the density of the water, and as a consequence changes the transport processes between sediment-water and water-atmosphere [62].

Thermal stratification and de-stratification are accompanied by a series of other physical and chemical changes in water. Of note is the vertical distribution of nutrients, with accumulation of substances and chemical elements in the hypolimnium during the stratification, and more homogeneous vertical concentrations in the water column after recirculation (rainy period).

Temperature directly influences the kinetics of metabolic processes (respiration, processes of organic matter decomposition, and solubility of gases) and acts directly on the water density, indicating the presence or not of thermal stratification.

\subsection{Ecological Flow}

The Brazilian Northeast emerges as a region that by its very nature needs attention to the water supply, with $87.8 \%$ of its territory in the semi-arid region. The low precipitation rates, the irregularity of its regime, high temperatures throughout the year, low thermal amplitudes (between $2{ }^{\circ} \mathrm{C}$ and $3{ }^{\circ} \mathrm{C}$ ), strong insolation, and high evapotranspiration rates tied to hydrogeological characteristics, such as the relevant presence of intermittent rivers, contribute to the observed reduced values of water availability.

Droughts from 2003 to 2016 led to 2773 municipalities decreeing an Emergency Situation (ES) or State of Public Calamity (SPC), and 1409 cities in the Northeast (78.5\% of the region) had to declare ES or SCP [29]. In most rivers, it is only possible to guarantee a continuous supply of water with the use of reservoirs, since these rivers naturally dry up during the drought, both due to low rainfall and low soil thickness.

Reservoirs mainly contribute to altering the natural river, despite energy generation, compromising the marginal lagoons and interrupting reproductive cycles and migratory fishes. In addition, hydroelectric reservoirs also allow fishing, leading to their decline. Damming is one of the most devastating forms of water management and can modify the natural hydrological regime of the river, as well as the quality of its water. These interventions cause changes in the habitats of fish spawning. The dams also interfere in the migratory route of fish, since they are insurmountable barriers in the routes of migratory species during fish breeding periods [63].

The regularization of the river by dams causes longitudinal discontinuity, forming a lentic environment upstream and a lotic environment downstream with changes in flow variability. Artificial control in hydrological dynamics alters magnitudes and frequencies of the vertical and lateral flows, affecting the whole fluvial system, both in the bed and in the flood plains and marginal lagoons [64].

Contrary to what occurs upstream, there is a reduction of the inundated area in the downstream sections impacting the connection between the fluvial plain lagoons, therefore the plains are exposed all year round or submerged in irregular periods, damaging species that spawn in the margins because 
the sudden oscillations may expose eggs, larvae, and fingerlings to desiccation and migratory fish species that spawn upstream of the dams but feed and grow in the marginal lagoons [65].

Downstream flows have been called residual, remaining, ecological, and environmental, and are increasingly essential for sustainable management of water resources [58]. The ecological flow is the quantity of water that must remain in the riverbed to meet the demands of the aquatic ecosystem for the preservation of flora and fauna related to the water body $[24,66]$. However, it should be considered as "the necessary flow to maintain the conditions of hydrological pulse, transport of sediments and nutrients, synchronicity of the life cycle of the wild species of fauna and flora, and the rate of disturbances necessary for the renewal and functioning of the ecosystems associated with the watercourse" [24].

The determination of the São Francisco River Basin Committee, no. 8, of July 29, 2004, Article 4, provisionally adopts the average daily flow of $1300 \mathrm{~m}^{3} \mathrm{~s}^{-1}$ as the minimum ecological flow in the mouth, until such value is reviewed or confirmed in the next review of the plan. Provisionally, with the approval of the SFRB Committee, this scheme is the best for multiple water uses [38]. According to Ramina [67], there is also a restriction on the operation of the hydroelectric plants on the São Francisco River in relation to the ichthyofauna and aquatic ecosystems.

The consideration of environmental ecological flows in the multiple uses of water is essential to reconcile the health of aquatic ecosystems with human needs [68]. In Brazil, the obligation to maintain a flow that allows the conservation and maintenance of aquatic ecosystems is provided by legislation [69]. The difficulty is defining what are the real values needed to meet these adopted demands; reference values for granting are based on statistical methods, not taking into account the real needs of the ecosystem [70]. The supply of surface water is usually estimated by means of reference flow rates, which represent the smallest of the historical series [71].

The São Francisco River Basin Water Resources Ten Year Plan [25] performs an important survey of water availability and presents an attempt to define ecological flows in the São Francisco River. This plan adopts the average daily flow of $1500 \mathrm{~m}^{3} \mathrm{~s}^{-1}$ as the minimum ecological flow in the mouth of the São Francisco river; a value determined by the Tennant method, which was questioned several times by the members of the Technical Boards of the São Francisco River Basin Committee (Cbhsf), as it only considers hydrological information and does not include demands such as that of aquatic biota and non-consumptive uses [72].

Ecological flow is a key element in dealing with the destruction of rivers, and consequently loss of biodiversity and related social benefits [33]. The proper balance between the use of water and the maintenance of its natural conditions allows the continued use of water, now and in the future. When this balance is not protected, functions offered by the waters will cease to exist, with enormous social losses [73].

\subsection{Water Flow-Through in the Reservoir}

Due to the large length of the Itaparica reservoir, the water body cannot be seen as a homogenous system. Firstly, the longitudinal differentiation of the São Francisco inflow must be considered, which will theoretically take two months to pass through the reservoir. Secondly, a transversal differentiation occurs, but transversal mixing is inhibited by shallow flooded areas with remaining trees and sometimes dense submerged macrophytes stands. Small, respectively short-term inflows from the watershed, such as drainage water, sewage from urban areas, contaminated water from aquaculture, and flash floods after heavy rains, lead to increased concentrations of contaminants near the shoreline due to simple dilution processes. Severe but local contamination problems occur within the more or less isolated bays of the reservoir, with high input rates from irrigated agriculture zones and small agro villages without sewage treatment.

Nowadays, these processes can be observed at Icó-Mandantes II bay, a $14 \mathrm{~km}$ long bay at the north shore of the Itaparica reservoir. Inflow water of bays is often also contaminated with pesticides and sewage due to agriculture and agricultural villages in the watershed. This leads to a high local 
risk of eutrophication and contamination with xenobiotics, and any reservoir management must be orientated to these high-risk areas, as the argument of high dilution by the river inflow is no longer acceptable (Table 3). The Icó-Mandantes bay has a much higher sensitivity for eutrophication than the total reservoir; the critical phosphorus $(\mathrm{P})$ load amounts to only $0.48 \mathrm{~g} \mathrm{~m}^{2}$ year $^{-1}$ compared to $2.84 \mathrm{~g} \mathrm{~m}^{2}$ year ${ }^{-1}$ of the total reservoir. The main nutrient fluxes into the water are quite different; the eutrophication of the Icó-Mandantes bay is mainly given by mineralization of desiccated soils and dead macrophytes (Egeria densa, see below), which are dried during low water levels, while the main nutrient input into the Itaparica reservoir occurs due to the São Francisco river inflow [56].

Table 3. Morphometric characteristics of Itaparica reservoir and Icó-Mandantes Bay and effects of reduced water exchange in the Icó-Mandantes bay [56].

\begin{tabular}{|c|c|c|c|}
\hline Parameters & & Itaparica Reservoir & Icó-Mandantes Bay \\
\hline Volume (max) $\mathrm{m}^{3}$ & & $10.7810^{9} \mathrm{~m}^{3}$ & $166.710^{6} \mathrm{~m}^{3}$ \\
\hline Length & & $148 \mathrm{~km}$ & $13.7 \mathrm{~km}$ \\
\hline Area $(\max ) \mathrm{km}^{2}$ & & 828 & 25.1 \\
\hline Water depth (max) m & & 101 & 22 \\
\hline Mean depth (high water level) m & & 13 & 6.8 \\
\hline Water residence time & & 61 days & $>1$ year \\
\hline Critical Phosphorus load $\left(\mathrm{g} \mathrm{m}^{-1}\right.$ year $\left.^{-1} \mathrm{P}\right)$ & & 2.84 & 0.48 \\
\hline Actual Phosphorus load $\left(\mathrm{g} \mathrm{m}^{-1}\right.$ year $\left.^{-1} \mathrm{P}\right)$ & & 3.45 & 1.55 \\
\hline P sources (with ranking osition) & $\begin{array}{l}1 . \\
2 . \\
3 .\end{array}$ & $\begin{array}{l}\text { São Francisco river inflow } \\
\text { Sub water basin } \\
\text { Net cage aquaculture }\end{array}$ & $\begin{array}{l}\text { 1. Desiccated shoreline area } \\
\text { 2. Sub water basin } \\
\text { 3. Water inflow from São } \\
\text { Francisco mainstream }\end{array}$ \\
\hline
\end{tabular}

In shallow areas mainly in bays of the reservoir, water heating occurs during the dry period and this promotes the development of weak thermal stratification $\left(\Delta \mathrm{C} \sim 2-4{ }^{\circ} \mathrm{C}\right)$ with high phytoplankton biomass in the epilimnion. However, water abstraction for irrigation and drinking water occurs near the margins in shallow water depths and with an associated elevated risk for contamination. About 15 years after damming, water abstraction during low water levels in Icó-Mandantes bay had to be replaced by separate drinking water.

\subsection{Water Level Variation}

The regular operational level of the São Francisco reservoir varies by about $5 \mathrm{~m}$ and large littoral areas periodically become dry. This leads to a complete failure of the littoral zonation with submerged and emerged aquatic plants, as well as the terrestrial vegetation strip. The sediments are also mineralized, leading to high nutrient input into the reservoir (Figure 5). Littoral fauna and flora are impeded, and the ecological value of the littoral zone is extremely reduced. The littoral zone is characterized by these periodical water level changes, and only a few pioneer organisms develop during inundation periods, including macrophytes such as Egeria densa, or some molluscs; thus, biodiversity is severely reduced. 


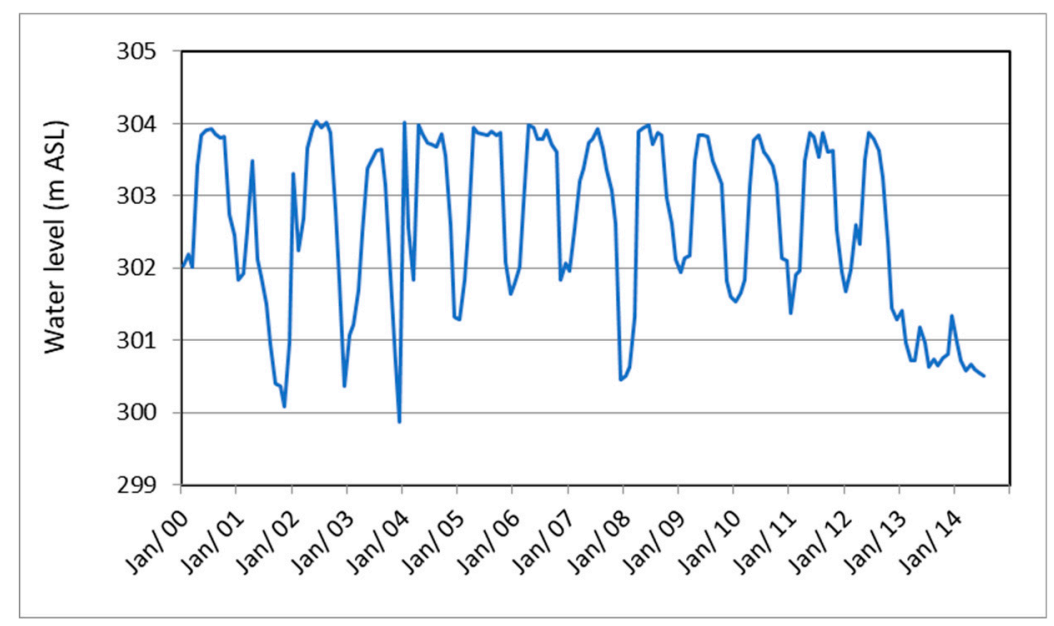

Figure 5. Upstream water level (meters above sea level, $m$ a.s.l.) in the Itaparica Reservoir during the last years; a long-lasting drought period has occurred since 2013 [74].

\subsection{Aquaculture}

Aquaculture is regarded as an opportunity to improve the economic situation, but the intensive implementation of net cages in the lake for tilapia culture (a goal in the Itaparica Reservoir is a yearly production of 43,000 t) leads to severe nutrient input into the reservoir.

For example, the net cage culture system "Jovens Criadores de Peixes" ("Young Fish Creators") of Moxotó, a reservoir below Itaparica, consists of 65 cages, each one at $4 \mathrm{~m}^{3}$ and $1000 \mathrm{~kg}$ of fish (Tilapia). The production cycle is only 6 months. Based on a food conversion factor of 1.4 and a production of 130 tons of fish per year, 180 tons of food are used yearly. This leads to an estimated annual input $2.2 \mathrm{t}$ of phosphorus, $11.5 \mathrm{t}$ of nitrogen, and about $36 \mathrm{t}$ of organic materials (food remains, feces), as well as an oxygen consumption (BOD5) of about $44 \mathrm{t}$ [75].

Investigations about the net cage culture system "Pé d'Água" ("Water Foot") in Moxotó Reservoir showed a decrease in oxygen saturation values in the water, especially near the ground, an accumulation of organic material and of phosphorous in the sediments below the cages, and a mass development of macrophytes in the inner part of the bay [53].

The modelling of nutrient emissions from a hypothetical aquaculture net cage production unit confirms the high impact on water quality; dissolved nutrient (nitrogen and phosphorus) emissions accumulate in the net cage area for a whole modelling period of 1 month and form a plume of contaminants without any dilution from the main stream of the São Francisco river [60].

\subsection{River Sedimentation}

An unpublished study conducted by the US Army Corps of Engineers and the São Francisco and Parnaíba Valley Development Company (Codevasf) reveals an amazing fact that translates something that has always been perceived in practice into numbers-the river bed receives no less than 23 million tons of sediment per year from the source in the Serra da Canastra in Minas Gerais, to the estuary in the Atlantic Ocean between Alagoas and Sergipe. In this study, 59 of the 73 evaluated sections presented silting.

José do Patrocínio Tomaz Albuquerque [76], an experienced hydrogeologist, points out that the natural transport of sediments to the sea has been drastically reduced, in part due to the construction of dams. "In periods of floods, sediments cannot reach the ocean in its entirety. This occurs for two reasons: a natural one related to the intensity of the maximum rains which occur less and less; and the other, being artificial, resulting from human action with the construction of surface reservoirs, which regulate but reduce the average natural flow of the river. This results in lower sediment transport capacity and consequent bed deposition", he explains. As solutions, besides recomposing 
the vegetation cover of the basin and revitalizing the springs and paths, he suggests "severe control of groundwater exploitation" [20].

\subsection{Social Impacts}

The municipalities around the Itaparica reservoir were flooded after construction of the dam. The economy of the municipalities was basically subsistence agriculture, which was unimportant in commerce and without industry. With the creation of the dam there was compulsory displacement of the population (about 40,000 people) of these municipalities to a location close to the old city, where the new city and settlements were built $[77,78]$, with consequent difficulties of adaptation in the new spaces. Furthermore, there was de-structuring of social relation networks, loss of arable land and improvements, and small and insufficient indemnities for land. The reallocation of the population was done by CHESF through compensating people for physical and economic damages concerning property (housing and economic activities) [32]. Various conflicts arose from the dispute over the availability of water and natural resources between the resettled population.

The following cities were built in order to compensate the impact of 10,500 families that lived in the area flooded by the reservoir: Petrolândia and Itacuruba in Pernambuco state, and Rodelas, Barra do Tarrachil, and Glória in Bahia state (Tables 4 and 5). Nine irrigation perimeters were built and implemented in the 1990's to serve the rural population, which are now in operational condition.

Table 4. Irrigation perimeters of the Itaparica System located in the State of Pernambuco.

\begin{tabular}{ccc}
\hline Perimeters & Number of Families & Start of the Operation \\
\hline Caraíbas & 1476 & 05.1998 \\
\hline Brígida & 443 & 02.1994 \\
\hline Icó-Mandantes & 802 & 03.1994 \\
\hline Barreiras & 721 & 05.1993 \\
\hline Manga de Baixo & 25 & 02.1987 \\
\hline Apolônio Sales & 100 & 05.1993 \\
\hline
\end{tabular}

Table 5. Irrigation perimeters of the Itaparica System located in the State of Bahia.

\begin{tabular}{ccc}
\hline Perimeters & Number of Families & Start of the Operation \\
\hline Pedra Branca & 711 & 07.1995 \\
\hline Rodelas & 508 & 05.1994 \\
\hline Glória & 124 & 04.1993 \\
\hline
\end{tabular}

It was up to Codevasf [79] to assume the operation and maintenance of the irrigation and drainage infrastructures as a form of support to the agreement. In turn, CHESF guaranteed economic and financial support to the agreement, transferring all the necessary resources to carry out the planned actions. There was a great mismatch from the intersection between the proposals of the program and what was actually accomplished. It is observed that the purpose of government policy was basically centered on two pillars: the expansion of energy generation and the large enterprises dominated by capital profit, covered by the structure of the State and by state capital.

\section{Discussion}

The management of water resources in Brazil is still incipient because there are incompatibilities between administrative and hydrological boundaries causing problems and legal and administrative inconsistencies. The Organization for Economic Co-operation and Development (OECD) [80] further points out that "the water resource plans at the national, state, local, and basin levels are poorly 
coordinated and not even put into practice". This explains the need for a mechanism to involve actors inclusively and transparently, and underlines the need of access to information to support policy makers and decision-making [22].

Water governance occurs in various spheres of power and involves diverse actors, turning it into a complex activity. The governance of the Itaparica reservoir is performed by environmental agencies (federal, state, and municipal), production sectors (fish farming, fishing, and agriculture), civil society, indigenous communities, professional associations, unions, and government agencies. Two important institutions are: Codevasf, in the development of the irrigated agriculture sector, and the and CHESF, as the plant's construction company [81].

According to Silva and Cirilo [82], the interinstitutional integration of a river basin can be analyzed by the integration between the water resource plans. The plans are essential elements for managing the water sector, since the master plans according to Law 9433/97 aim to base and implement the National Water Resources Policy.

Siegmund-Schultze et al. [83] point out that although the São Francisco River Basin Committee (Cbhsf) is active, participation is not homogeneous, and it does not equitably represent all the regions of the river basin. Part of the São Francisco region has a gap in participation of basin actors in defining the implementation instrument goals defined in the National Policy of Water resources.

Some severe environmental problems and impacts are obvious thirty years after damming, mainly inadequate land use with salinization problems, eutrophication of the reservoir, increasing water contamination by aquaculture in ponds and net cages without environmental control, and contamination of the reservoir with sewage. The eutrophication process is a well-known phenomenon for a new dammed reservoir called the trophic upsurge. The flow regime has changed to a lentic (standing water) environment, with increased sedimentation. The oxygen quota is burdened by reduced sedimentation and reduced physical water re-aeration and increased oxygen consumption due to intensive mineralization processes of the inundated vegetation and autochthon production.

This trophic upsurge is caused by the change of the hydrological conditions and by nutrient release from the inundated areas. The inundated vegetation and soils contain high amounts of nutrients, which are continuously released by mineralization after flooding. It must be considered that the deposited soils along a river are normally rich in nutrients, because these areas had been used for agriculture with fertilizer application, among others. These processes promote eutrophication of reservoirs. The eutrophication process is strongly related to rivers being dammed, and good river water quality does not give any guarantee of good reservoir water quality. Thus, new technologies, such as water reuse, water saving irrigation systems, treatment of drainage water, and protection of the reservoir by a buffer zone without any land use along the shoreline must be applied [50].

In social aspects, some resettled families do not have the property rights of the land where they live, and marketing of agricultural and lake fishery products is still insufficient. The migration of people into the river basin, especially to the reservoir's margin zone, leads to a so-called cultural eutrophication due to increased agricultural use with emission of irrigation water after percolation, or of drainage water by sewage input and by other activities, such as aquaculture or raising livestock.

The focus of interest must be the eutrophication-related processes in reservoirs, such as input of nutrients, nutrient concentration of river inflow versus mineralization of inundated vegetation of soils $[77,84]$, the nutrient leaching processes of desiccated lake shore areas due to water level variation [17], the occurrence of toxic cyanobacteria [85], the formation of organic rich sediments, periodical anoxic conditions in the sediment and the hypolimnic water [86], and also the promotion of water-borne diseases, such as schistosomiasis by intensive macrophyte growth [87].

Aquaculture activity must also be regarded as severely impacting on water quality, but the strategy to develop a capacity model can minimize contamination effects. The main effects of cage culture are the increase of eutrophication processes, the accumulation of organic rich sediments below the cages, and the decrease of oxygen in the sediments, the sediment contact water zone, and in the hypolimnion during the stratification period $[75,88]$. In general, these complex interactions of aquaculture emissions 
to lake biocenosis do not allow high loading, and the development of aquaculture systems such as the fish cage culture must be critically evaluated if no future-oriented concepts, such as feedback systems (reuse of aquaculture waste for other applications like irrigation) or "blue" aquaculture, are applied [64,66,75]. According to Arruda [89], among preventive measures to control eutrophication, there are: withdrawal of nutrients through tertiary treatment of domestic sewage; treatment of industrial effluents; reduction of the use of agricultural fertilizers and the application of a management tool for soil fertilization practices; restoration of riparian forests and urban drainage control.

In the future, the significance of water quantity and quality will continue to increase because long-term droughts are occurring more frequently due to climate change. The consequences are conflicts in water uses, stressed ecosystems, and an increase in nutrient and contaminant concentrations.

These management tools support oligotrophication of a water body, and the goal of any environmental policy must be to guarantee sufficient water quantity and quality for long-term and sustainable water uses, including ecological flow and biodiversity [16].

\section{Conclusions}

The Itaparica Reservoir was developed as a hydroelectric power system about 30 years ago without sufficient environmental impact studies and without any water resource management planning. In the meantime, the water use has become more differentiated and the Itaparica Reservoir serves as drinking water, irrigation water, and in some areas for industrial water use, aquaculture systems, and recreation. Additionally, long lasting droughts promote water scarcity and lead to more environmental impact, such as lack of ecological flow and mass development of toxic algae.

Water governance occurs in various spheres of power and involves diverse actors, making it a complex activity. For better governance performance, it is necessary that participation of basin actors should became more homogeneous, focusing on multiple uses and knowledge. Thus, an integrated river basin management system with an adequate, local strategy must be developed to guarantee more sustainable use of land, as well as sufficient water quantity and quality $[2,16,90]$.

A large reservoir must be regarded as a complex system with a significant longitudinal and transversal differentiation, and local mass development of algae or macrophytes must be considered. An evaluation of contaminants only on the basis of inflow and dilution does not consider the high contamination risk within more or less isolated bays of a reservoir. Thus, new technologies, such as water reuse, water saving irrigation systems, drainage water treatment, and protection of the reservoir by a buffer zone without any land use along the shoreline [34] must be applied.

Author Contributions: Supervision, M.C.S.; writing—original draft, É.A.T.M.; writing—review and editing, G.G. Funding: This research was funded by Bundesministerium für Bildung und Forschung: Project INNOVATE.

Acknowledgments: This study was supported by the Federal Ministry of Education and Research (BMBF) and the Ministry of Science, Technology, Innovation and Communications (MCTIC) through Project Innovate; CAPES (Coordination for the Improvement of Higher Education Personnel) and DAAD/Germany (German Academic Exchange Service) through the Probral Program and (CHESF) Companhia Hidro Elétrica do São Francisco.

Conflicts of Interest: The authors declare no conflict of interest.

\section{References}

1. Tundisi, J.G.; Matsumura-Tundisi, T. Integration of research and management in optimizing multiple uses of reservoirs: The experience in South America and Brazilian case studies. Hydrobiologia 2004, 500, 231-242. [CrossRef]

2. Andreoli, C.V.; Carneiro, C. (Eds.) Integrated Management of Eutrophic Supply Streams; Sanepar: Curitiba, Brazil, 2005; p. 500.

3. Gunkel, G.; Sobral, M. (Eds.) Reservoirs and River Basins Management: Exchange of Experience from Brazil, Portugal and Germany; Universitätsverlag der TU: Berlin, Germany, 2007; p. 279. ISBN 978-3-7983-2056-7. 
4. Campos, V.N.O.; Fracalanza, A.P. Water Governance in Brazil: Conflicts over the Appropriation of Water and the Search for Integration as A Consensus. Ambient. Soc. 2010, 13, 365-382. [CrossRef]

5. Santos, M.E.P.; Moraes, L.R.S.; Rossi, R.A. Water as A Right and as A Commodity: The Challenges of Politics; Bahia Análise \& Dados; Superintendency of Economic and Social Studies of Bahia (Sei): Salvador-BA, Brazil, 2013; Volume 23, pp. 437-459.

6. ANA-National Water Agency Institutional Booklet. 2014. Available online: file://C:/Users/erika/Downloads/ 20140328173505_Cartilha_institucional_ANA_2013_-_INGLES_\%20(1).pdf (accessed on 11 May 2019).

7. Pagnoccheschi, B. Governability and Governance of Water in Brazil. In Environmental Governance in Brazil: Institutions, Actors and Public Policies; Adriana Maria Magalhães de Moura [Org.]; IPEA: Brasília, Brazil, 2016; p. 352.

8. Tundisi, J.G. Limnology in the 21st Century: Perspectives and Challenges. In Proceedings of the Opening Conference 7th Brazilian Congress of Limnology, Florianópolis, Brazil, 19-22 July 1999; International Institute of Ecology: Hamburg, Germany, 1999; p. 24.

9. Souza-Júnior, C.B.; Siegmund-Schultze, M.; Köppel, J.; Sobral, M.C. Signs of a chronic problem: Need for water governance to promote basin committees, coordinate plans and manage information. Rev. Ambient. Água 2017, 12, 1054-1067.

10. Rosa, L.P.; Matvienko, V.; dos Dantos, M.; Sikar, E. First Brazilian Inventory of Anthropogenic Greenhouse Gas Emissions; Background Reports; Carbon Dioxide and Methane Emissions from Brazilian Hydroelectric Reservoirs; Ministry of Science and Technology: Brasília, Brazil, 2002; p. 119.

11. Fearnside, P.M. Do hydroelectric dams mitigate global warming? The case of Brazil's Curuá-Una dam. Mitig. Adapt. Strateg. Glob. Chang. 2005, 10, 675-691. [CrossRef]

12. Gunkel, G.; Sobral, M.C. Water in the Megacity Recife, Pernambuco, Brazil: Water Supply and Discharge. In 2nd International Congress on Environmental Planning and Management, Visions Implementations Results; Universitätsverlag der TU Berlin: Berlin, Germany, 2007; pp. 237-241. ISBN 978-3-7983-2049-9.

13. Gunkel, G.; Sobral, M. Re-oligotrophication as a challenge for tropical reservoir management with reference to Itaparica Reservoir, São Francisco, Brazil. Water Sci. Technol. 2013, 67, 708-714. [CrossRef] [PubMed]

14. Vieira, V.P.P.B.; Gondim Filho, J.G.C. Freshwater in the Semi-Arid. In Sweet Waters in Brazil; Rebouças, A., Braga, B., Tundisi, J.G., Eds.; Escrituras Editora: São Paulo, Brazil, 2006.

15. Gondim, J.; Fioreze, A.P.; Alves, R.F.A.; Souza, W.G. The current drought in the Northeastern Semi-arid-Impacts on water resources. Parc. Estrat. Brasilia-DF 2017, 22, 277-300.

16. Gunkel, G.; Aleixo da Silva, J.A.; Sobral, M.C. (Eds.) Sustainable Management of Water and Land in Semiarid Areas; Editora Universitária UFPE: Recife, Brazil, 2013; p. 295. ISBN 978-85-415-0259-7.

17. Gunkel, G.; Selge, F.; Keitel, J.; Lima, D.; Calado, S.; Sobral, M.; Rodriguez, M.; Matta, E.; Hinkelmann, R.; Casper, P.; et al. Water management and aquatic ecosystem services of a tropical reservoir (Itaparica, São Francisco, Brazil). Region. Environ. Chang. 2018, 18, 1913-1925. [CrossRef]

18. Siegmund-Schultze, M.; Sobral, M.C.; de Moraes, M.M.G.A.; Köppel, J. The legacy of large dams and their effects on the water-land nexus. Reg. Environ. Chang. 2018, 18, 1883-1888. [CrossRef]

19. ANA-National Water Agency. Superintendence of Water and Soil Conservation. Integrated Management Project for Land-Based Activities in the São Francisco Basin. Technical Study of Support to PBHSF $N^{\circ} 12$. Irrigated Agriculture; National Water Agency: Brasília, Brazil, 2003.

20. Ribeiro, L. Withdrawal of Water for Supply and Irrigation Helps to Dry the São Francisco River. 2017. Available online: https://www.em.com.br/app/noticia/gerais/2017/09/26/interna_gerais,903466/superexploracao-daagua-ajuda-a-secar-o-rio-sao-francisco.shtml (accessed on 23 November 2018).

21. Oliveira, E.G.; Santos, F.J.S. Fish-Farming and Challenges of Producing in Regions with Water Scarcity; Animal Science: Fortaleza, Brazil, 2015; Volume 25.

22. Sobral, M.C. Ist die Unweltverträglichkeitsprüfung ein Wirksames Instrument des Unweltschutzes in Brasilien? Ph.D. Thesis, Institute of Environmental Planning, Technical University Berlin, Berlin, Germany, 1991.

23. Sobral, M.C.; Carvalho, R.C.; Figueiredo, R.C. Environmental Risk Assessment of Multipurpose Use of Reservoirs in Semiarid Area of São Francisco River, Brazil. In Reservoir and River Basin Management; Exchange of Experiences from Brazil, Portugal and Germany; Gunkel, G., Sobral, M.C., Eds.; UFPE/Tu-Berlin: Recife/Berlin, Germany, 2007.

24. Coelho, M.A.T. The Misplaces of the São Francisco; Paz e Terra: São Paulo, Brazil, 2005. 
25. CBHSF-São Francisco River Basin Committee. Water Resources Plan for the São Francisco River Basin 2016-2025. RP1A-Diagnosis of the Technical and Institutional Dimension. Volume 7-Uses, water balance and synthesis of the diagnosis, Rev.1-August; Nemus: Lisboa, Portugal, 2015.

26. ANA-National Water Agency. Situation Room. São Francisco. Available online: http://www3.ana.gov.br/ portal/ANA/sala-de-situacao/sao-francisco\# (accessed on 23 November 2018).

27. Sobral, M.C.; Assis, J.M.O.; Oliveira, C.R.; Silva, G.M.N.; Morais, M.; Carvalho, R.M.C. Impact of Climate Change on Water Resources in the Sub-Middle of the São Francisco River Basin-Brazil. REDE Rev. Eletrôn. Prodema Fortaleza 2018, 12, 95-106.

28. Marengo, J.A.; Alves, L.; Valverde, M.; Rocha, R.; Laborbe, R. Extreme Events in Regional Climate Scenarios in Brazil and South America for the 21st century: Future Climate Projections Using Three Regional Models; Report 5, Ministry of the Environment (MMA), Secretariat of Biodiversity and Forests (SBF), Directory of Biodiversity Conservation (DCBio). Global Climate Change and Effects on Biodiversity-Subproject: Characterization of the Current Climate and Definition of Climate Change for the Brazilian Territory Throughout the 21st century; Center for Management and Strategic Studies (CGEE): Brasília, Brazil, 2007.

29. ANA-National Water Agency. Conjuncture of Water Resources in Brazil 2017; Full Report; ANA: Brasília, Brazil, 2017; p. 139.

30. MMA-Ministry of the Environment. Program for the Revitalization of the São Francisco River Basin; Maurício Cortines Laxe et al. (Coord.); 2004. Available online: http://www.mma.gov.br/estruturas/PRSF/_arquivos/ diag.pdf (accessed on 21 December 2018).

31. ANA-National Water Agency. Monitoring Report of the São Francisco River Reservoirs; ANA-National Water Agency: Brasília, Brazil, 2018; Volume 13, pp. 1-15.

32. CEPEL-Center for Electrical Energy Surveys. Newave-Planning Model for the Operation of Long-Term and Long-Term Interconnected Hydrothermal Systems. 2017. Available online: http://www.cepel.br/produtos/newave-modelo-de-planejamento-da-operacao-de-sistemas-hidrotermicosinterligados-de-longo-e-medio-prazo.htm (accessed on 17 November 2018).

33. IICA-Inter-American Institute for Cooperation on Agriculture. Chesf/IICA Technical Cooperation Project; Final Report IICA; IICA: Recife, Brazil, 2001.

34. Brazil CONAMA Resolution N. 302. Provides on the Parameters, Definitions and Limits of Areas for the Permanent Preservation of Artificial Reservoirs and the REGIME of use of the Environment; Official Gazette of the Federative Republic of Brazil: Brasília, Brazil, 2002.

35. SUDENE-Northeast Development Authority. Monthly Pluviometric Data from the Northeast; Pluviometry Series, 6; SUDENE: Recife, Brazil, 1990.

36. CODEVASF-Development Company of the São Francisco and Parnaíba Valleys. Technical Assistance and Rural Extension Service for Resettled Farmers as A Result of the Construction of the Itaparica Dam-Lot 2: Lake Edge; Final report; Development Company of the São Francisco and Parnaíba Valleys: Petrolina, Brazil, 1998.

37. EMBRAPA-Brazilian Agricultural Research Corporation. Agroecological Zoning of the State of Pernambuco; Brazilian Agricultural Research Corporation. Embrapa Soils: Recife, Brazil, 2001.

38. Cavedon, A.D. Classification, Morphological, Physical and Chemical Characteristics of the Main Soils Occurring in the Brazilian Semi-Arid Region. In Symposium on the Caatinga and its Rational Exploration; Universidade Estadual de Feira de Santana: Brasília, Brazil, 1986; pp. 73-91.

39. de Araújo Filho, J.C.; Gunkel, G.; Sobral, M.C.M.; Kaupenjohann, M.; Lopes, H.L. Soil attributes functionality and water eutrophication in the surrounding area of Itaparica Reservoir, Brazil. Campina Grande 2013, 17, 1005-1013. [CrossRef]

40. Brazil Ministry of the Environment. Revitalization Actions in the São Francisco River Basin; Ministry of the Environment: Brasília, Brazil, 2004.

41. Brazil Ministry of the National Integration. Integration Project of the São Francisco River with Hydrographic Basins of the Northeast of the North; Environmental Impact Report-RIMA. 2009. Available online: http://www.integracao.gov.br/saofrancisco/integracao/rima.asp (accessed on 23 July 2018).

42. Santos, V.S.; Curi, W.F. Sustainability of the Water Resources Use of the Epitácio Pessoa Reservoir through a Multiobjective Optimization Model. REUNIR Revista de Administração Contabilidade e Sustentabilidade 2014, 4, 95-112. [CrossRef]

43. MI-Ministry of National Integration; Secretariat of Water Infrastructure-SIH. Integration Project of the São Francisco River; Executive Summary; MI-Ministry of National Integration: Brasília, Brazil, 2015; p. 15. 
44. Tundisi, J.G. Climate. In Limnological Studies on the Rio Doce Valley Lakes; Tundisi, J.G., Saijo, Y., Eds.; Brazilian Academy of Sciences: São Carlos, Brazil, 1997; pp. 7-11.

45. Tundisi, J.G. New Perspectives for the Management of Water Resources. Revista USP 2006, 70, $24-35$. [CrossRef]

46. Barros, A.C. Evolution of hydrobiological factors in the reservoir of Itaparica-River São Francisco (1987, 1989 e 2002). Master's Thesis, Postgraduate Program in Environmental Management and Policies, UFPE, Recife, Brazil, 2004.

47. Brazil CONAMA Resolution 01. Provides Basic Criteria and General Guidelines for the Environmental Impact Assessment; Official Gazette of the Federative Republic of Brazil: Brasília, Brazil, 1986.

48. Melo, G.L. Evaluation of water quality in reservoirs interconnected with the São Francisco River located in the Brazilian semiarid. Ph.D. Thesis, Graduate Program in Civil Engineering, Universidade Federal de Pernambuco, Recife, Brazil, 2011.

49. Winton, R.S.; Calamita, E.; Werli, B. Reviews and Syntheses: Dams, Water Quality and Tropical Reservoir Stratification. Biogeosciences 2019, 16, 1657-1671. [CrossRef]

50. Gunkel, G. Hydropower-A green energy? Tropical reservoirs and greenhouse gas emissions. Clean 2019, 37, 726-734. [CrossRef]

51. CHESF-São Francisco Hydroelectric Company. Limnological monitoring Program and Evaluation of the Water Quality of the Itaparica Reservoir; 1st Annual Report; Hydroelectric Company of São Francisco: Recife, Brazil, $2004 ;$ p. 77.

52. Gunkel, G. Contamination and eutrophication risks of a reservoir in the semi-arid zone: Reservoir Itaparica, Pernambuco, Brazil. In Reservoirs and River Basins Management: Exchange of Experience from Brazil, Portugal and Germany; Gunkel, G., Sobral, M.C., Eds.; Universitätsverlag der Technischen Universität Berlin: Berlin, Germany, 2007; pp. 81-95.

53. Gunkel, G.; Steemann, J.; Sobra, M.C. Carrying capacity limits in net cage fish production in water reservoirs. In Sustainable Management of Water and Land in Semiarid Areas; Editora Universitária; Gunkel, G., Aleixo da Silva, J.A., Sobral, M.C., Eds.; UFPE: Recife, Brazil, 2013; pp. 99-117. ISBN 978-85-415-0259-7.

54. Siegmund-Schultze, M.; Araújo, G.J.F.; Carvalho, R.M.C.M.O.; Gomes, E.T.A.; Köppel, J.; Rodorff, V. Which governance options promote sustainable landscapes and economic viability in a semi-arid reservoir area? Poster. In Proceedings of the UNCCD 2nd Scientific Conference: Economic Assessment of Desertification, Sustainable land Management and Resilience of Arid, Semi-Arid and Dry Sub-Humid Areas, Bonn, Germany, 9-12 April 2013.

55. Vollenweider, R.A. Advances on defining critical loading levels for phosphorus in lake eutrophication. Memorie dell'Istituto Italiano di Idrobiologia 1976, 33, 53-83.

56. Selge, F.; Matta, E.; Hinkelmann, R.; Gunkel, G. Nutrient load concept-reservoir vs. bay impacts: A case study from a semi-arid watershed. Water Sci. Technol. 2016, 74, 1671-1679. [CrossRef]

57. Teixeira, M.G.L.C.; Costa Mda, C.; de Carvalho, V.L.; Pereira Mdos, S.; Hage, E. Gastroenteritis epidemic in the area of the Itaparica, Bahia, Brazil. Bull. Pan. Am. Health Organ. 1993, 27, 244-253.

58. Bini, L.M.; Thomaz, S.M. Prediction of Egeria najas and Egeria densa occurrence in a large subtropical reservoir (Itaipu Reservoir, Brazil-Paraguay). Aquatic Bot. 2005, 83, 227-228. [CrossRef]

59. Lima, D.B.M. The Role of Water Level Fluctuations in the Promotion of Phytoplankton and Macrophyte Pioneer Species in a Tropical Reservoir in the Brazilian Semiarid. Ph.D. Thesis, Berlin University of Technology, Berlin, Germany, 2017; 120p. Available online: https://depositonce.tu-berlin.de/handle/11303/7705 (accessed on 15 September 2018).

60. Martins-Melo, F.R.; Pinheiro, M.C.C.; Ramos, A.N.; Alencar, C.H.; de, M.; Bezerra, F.S.; Heukelbach, J. Spatiotemporal Patterns of Schistosomiasis-Related Deaths, Brazil, 2000-2011. Emerg. Infect. Dis. 2015, 21, 1820-1823. [CrossRef]

61. ANA-National Water Agency. Reservoir Monitoring System. Available online: http: //sar.ana.gov.br/MedicaoSin?dropDownListEstados=6\&dropDownListReservatorios=19121\&dataInicial= 01\%2F01\%2F1970\&dataFinal=01\%2F01\%2F2019\&button=Buscar (accessed on 2 March 2019).

62. Ferreira, D.M.; Cunha, C. Numerical simulation of the temperature dynamics at Rio Verde Reservoir. Eng. Sanit. Ambient. 2013, 18. [CrossRef]

63. ANA-National Water Agency. Conjuncture of Water Resources in Brazil 2017; Full Report; ANA-National Water Agency: Brasília, Brazil. 
64. Gyllenhammar, A.; Håkanson, L. Environmental consequence analyses of fish farm emissions related to different scales and exemplified by data from the Baltic-A review. Mar. Environ. Res. 2005, 60, 211-243. [CrossRef]

65. Bizerril, C.R.S.F.; Primo, P.B.S. Inland Water Fishes of the State of Rio de Janeiro; FEMAR—SEMADS: Rio de Janeiro, Brazil, 2001; pp. 1-417.

66. Matta, E.; Selge, F.; Gunkel, G.; Rossiter, K.; Jourieh, A.; Hinkelmann, R. Simulations of nutrient emissions from a net cage aquaculture system in a Brazilian bay. Water Sci.Technol. 2016, 73, 2430-2435. [CrossRef]

67. Ramina, R.H. Consultancy and Specialized Face-to-Face Advisory for Studies of the reduced Flows in an Emergency in the São Francisco River from the São Francisco Hydroelectric Power Plant and Proposing Alternatives that Guarantee the Multiple Use of the Waters. Product 02-Design of a Robust Strategy for the Management of Multiple uses in the São Francisco River Basin. Scenarios 2014, 2, 1-49.

68. Amorim, F.B. Impact of the Adoption of Ecological Flows in the Lower Course of the São Francisco River on the Generation of Energy. Master's Thesis, Graduate Program in Urban Environmental Engineering, Federal University of Bahia-UFB, Salvador-BA, Brazil, 2009; p. 114.

69. Brazil National Policy on Water Resources. National Policy on Water Resources. Law No. 9,433, of 8 January 1997; Official Gazette of the Federative Republic of Brazil: Brasília, Brazil, 1997.

70. Belico, J.C.B.; Lisboa, L.; Guedes, H.S.; Silva, D.D. Comparison between Minimum Reference Flows for River Formoso-MG; Enciclopedia Biosfera, Centro Científico Conhecer: Goiânia, Brazil, 2013; Volume 9, p. 718.

71. Baena, L.G.N.; Silva, D.D.; Pruski, F.F.; Calijuri, M.L. Spatialization of Q7,10, Q90\% and Q95\% aiming at the management of water resources: A case study for the Paraíba do Sul river basin. Engenharia na Agricultura 2004, 1, 24-31.

72. Aquino, I.H.V. Minimum Flow Requirements in the Transition of Water Bodies from State to Federal Domain: Application in the Rio Preto Basin (DF/GO/MG). Master's Thesis, Post-Graduation Program in Civil and Environmental Engineering, Universidade de Brasília, Brasília, Brazil, 2012; pp. 1-123.

73. IUCN-International Union for Conservation of Nature and Natural Resources. The Essentials of Environmental Flows; IUCN: Gland, Switzerland, 2003.

74. ONS-National Electrical System Operator. Operation History. Hydrological Data/Levels. Itaparica Reservoir. Available online: http://ons.org.br/Paginas/resultados-da-operacao/historico-da-operacao/dados_ hidrologicos_niveis.aspx (accessed on 15 May 2019).

75. Gunkel, G.; Matta, E.; Selge, F.; Nogueira da Silva, G.M.; Sobral, M. Carrying capacity limits of net cage aquaculture for Brazilian reservoirs. Rev. Bras. Cienc. Ambient. 2015, 36, 128-144. [CrossRef]

76. Albuquerque, J.P.T. Water security for human supply in the Northeast. In Proceedings of the XII Symposium on Water Resources in the Northeast, Natal, Brazil, 4-7 November 2014.

77. Lewis, W.M., Jr. Basis for the protection and management of tropical lakes. Lakes Res. Res Manag. 2000, 5, 35-48. [CrossRef]

78. Lima, S.R.R. Itaparica Reservoir: Twenty Years after the Resettlement -(des)-Involvement and (des)-Structuring Lives. In Proceedings of the II Social Sciences and Dams Meeting, Salvador, Bahia, Brazil, 19-22 November 2007.

79. CODEVASF-Development Company of the São Francisco and Parnaíba Valleys Itaparica System. 2019. Available online: https://www2.codevasf.gov.br/programas_acoes/sistema-itaparica-1?set_language=en\&cl= en (accessed on 2 March 2019).

80. Organization for Economic Cooperation and Development (OECD). Principles on Water Governance. 2015. Available online: http://www.oecd.org/gov/regional-policy/OECD-Principles-on-WaterGovernancebrochure.pdf (accessed on 15 September 2018).

81. Rodorff, V.; Siegmund-Schultze, M.; Köppel, J.; Torres, E. Challenges of Multi-Level Governance in The São Francisco Watershed: Inter-And Transdisciplinary Perceptions. RBCIAMB 2015, 36, 19-44. [CrossRef]

82. Silva, S.R.; Cirilo, J.A. The planning of water resources in the São Francisco river basin. Revista de Gestão de Água da América Latina-REGA 2011, 1, 47-64. [CrossRef]

83. Siegmund-Schultze, M.; Rodorff, V.; Köppel, J.; Sobral, M.C. Paternalism or participatory governance? Efforts and obstacles in implementing the Brazilian water policy in a large watershed. Land Use Policy 2015, 48, 120-130. [CrossRef] 
84. IETC - International Environmental Technology Centre. Planning and Management of Lakes and Reservoirs: Una Visión Integral de la Eutroficación; UNEP International Environmental Technology Centre, UNEP/Earthprint: Osaka, Japan, 2000.

85. Molica, R.J.R.; Oliveira, E.J.A.; Carvalho, P.V.V.C.; Costa, A.N.S.F.; Cunha, M.C.C.; Melo, G.L.; Azevedo, S.M.F.O. Occurence of saxitoxins and an anatoxin-a(s)-like anticholinesterase in a Brazilian drinking water supply. Harmful Algae 2005, 4, 743-753. [CrossRef]

86. Hupfer, M.; Lewandowski, J. Retention and early diagenetic transformation of phosphorus in Lake Arendsee (Germany)-Consequences for management strategies. Archiv für Hydrobiologie 2002, 164, 143-167. [CrossRef]

87. Gonzales, E. Schistosomiasis, cercarial dermatitis and marine dermatitis. Dermatol. Clin. 1989, 7, $291-300$. [CrossRef]

88. Tacon, A.G.J.; Forster, I.P. Aquafeeds and the environment: Policy implications. Aquaculture 2003, 226, 181-189. [CrossRef]

89. Arruda, N.O. Phosphorus Control in Itaparica Reservoir in the Brazilian Semiarid Region. Ph.D. Thesis, Federal University of Pernambuco, Recife, Brazil, 2015.

90. Straškraba, M.; Tundisi, J.G. Reservoir Water Quality Management; ILEC: Kusatsu, Japan, 1999; Volume 9, pp. 1-227.

(C) 2019 by the authors. Licensee MDPI, Basel, Switzerland. This article is an open access article distributed under the terms and conditions of the Creative Commons Attribution (CC BY) license (http://creativecommons.org/licenses/by/4.0/). 